\title{
35. MESOZOIC BIOSTRATIGRAPHIC, PALEOENVIRONMENTAL, AND PALEOBIOGEOGRAPHIC SYNTHESIS, EQUATORIAL ATLANTIC ${ }^{1}$
}

\author{
M. Moullade, ${ }^{2}$ D.K. Watkins, ${ }^{3}$ F.E. Oboh-Ikuenobe, ${ }^{4}$ J.-P. Bellier, ${ }^{5}$ E. Masure, ${ }^{5}$ A.E.L. Holbourn, ${ }^{6}$ J. Erbacher, ${ }^{7}$ W. Kuhnt, ${ }^{6}$ \\ T. Pletsch, ${ }^{6}$ M.A. Kaminski, ${ }^{8}$ R. Rauscher, ${ }^{9}$ S. Shafik, ${ }^{10}$ O. Yepes, ${ }^{4}$ J. Dejax,${ }^{11}$ J.M. Gregg, ${ }^{4}$ I.C. Shin, ${ }^{12}$ and M. Schuler ${ }^{9}$
}

\begin{abstract}
Cretaceous sediments from Ocean Drilling Program Leg 159 on the Côte d'Ivoire-Ghana Marginal Ridge (CIGMR), eastern equatorial Atlantic, are characterized by distinct stratigraphic changes in sedimentary facies associated with changes in the composition of the clayey and organic fractions, as well as of the calcareous nannofossil, radiolarian, foraminiferal, and palynomorph assemblages. In the absence of reliable magnetostratigraphic information, an integrated biostratigraphy provides the only means used to calibrate the geologic history of the Leg 159 area.

The existence of marine depositional environments as early as the late Aptian to early Albian close to the Leg 159 drill sites puts constraints on the timing of the opening of the equatorial Atlantic gateway. Marine sedimentation on the ridge suggests that the West African and South American cratons were largely detached at this segment of the margin by the middle to late Albian. During the Cenomanian to Coniacian the ridge appears to have remained in an elevated position with concurrent low deposition or condensation (Site 959), high carbonate debris accumulation (Site 960), and even erosion (Site 962). Total organic Carbon measurements and microfaunal data lead us to suggest that, following the early opening of the seaway during the Albian, circulation remained restricted in the fragmented sub-basins of the CIGMR. It probably was not until the Santonian that a deep-water connection and circulation system became established between the Central and the South Atlantic. The sedimentary and faunal record at Site 959 show that a rapid subsidence occurred during the Santonian, with sub-calcite compensation depth conditions maintained until and beyond the Cretaceous/Tertiary boundary.
\end{abstract}

\section{INTRODUCTION}

One of the main objectives of Ocean Drilling Program (ODP) Leg 159 in the Gulf of Guinea was to investigate the Cretaceous tectonic, sedimentary, and paleoceanographic history of the Côte d'IvoireGhana Transform Margin (Fig. 1). This area is of critical importance in understanding the history of the Atlantic Ocean, since it was one of the last to open during the initial spreading phase. Furthermore, it was directly involved in the establishment of an early connection between the spreading North and South Atlantic Oceans. Thus, the Cretaceous sedimentary record of this area should yield important clues to the incipient evolution of the Equatorial Atlantic.

The main purpose of this paper is to summarize and to correlate the biostratigraphic findings of the various paleontological contribu-

'Mascle, J., Lohmann, G.P., and Moullade, M. (Eds.), 1998. Proc. ODP, Sci. Results, 159: College Station, TX (Ocean Drilling Program)

${ }^{2}$ Laboratoire de Micropaléontologie et de Géologie Marines, CNRS UMR 6526 et GDR 88, Université de Nice-Sophia Antipolis, Parc Valrose, 06108 Nice Cedex 2, France.moullade@unice.fr

${ }^{3}$ Department of Geology, University of Nebraska, Lincoln, NE 68588-0340, U.S.A.

${ }^{4}$ Department of Geology and Geophysics, University of Missouri-Rolla, Rolla, MO 65409-0410, U.S.A.

${ }^{5}$ Laboratoire de Micropaléontologie, URA CNRS 1761, Université Pierre et Marie Curie, 4 place Jussieu, 75252 Paris Cedex 05, France.

${ }^{6}$ Geologisch-Paläontologisches Institut der Christian-Albrechts-Universität zu Kiel, Olshausenstrasse 40, D-24118 Kiel, Federal Republic of Germany.

${ }^{7}$ Institut u. Museum für Geologie/Paläontologie der Universität Tübingen, Sigwartstrasse 10, D-72076, Tübingen, Federal Republic of Germany.

${ }^{8}$ Research School of Geological and Geophysical Sciences, Birkbeck College and University College London, Gower Street, London WC1E 6BT, United Kingdom.

${ }^{9}$ Centre de Géochimie de la Surface (CNRS), 1 rue Blessig, 67084 Strasbourg Cedex, France.

${ }^{10}$ Marine Science and Petroleum Geology Program, Australian Geological Survey Organization, GPO Box 378, Canberra, ACT 2601, Australia.

${ }^{11}$ Laboratoire de Paléontologie, Museum National d'Histoire Naturelle, 8 rue Buffon, 75005 Paris, France.

${ }^{12}$ Korea Ocean Research and Development Institute, Ansan, P.O. Box 29, Seoul 425-600, Korea. tions dealing with Cretaceous sediments (planktonic foraminifers: Bellier, Chap. 27; radiolarians: Erbacher, Chap. 29; benthic foraminifers: Holbourn and Kuhnt, Chap. 30; Holbourn and Moullade, Chap. 28; Kuhnt et al., Chap. 31; palynomorphs [dinoflagellates and pollen]: Masure et al., Chap. 24; Oboh-lkuenobe et al., 25; calcareous nannofossils: Watkins et al., Chap. 26; all this volume). Some unpublished observations and updates are also included. Cretaceous sedimentary rocks were recovered from four sites $(959,960,961$, and 962) drilled on the Côte d'Ivoire-Ghana Marginal Ridge (CIGMR), which extends along the southern side of the Deep Ivorian Basin. An integrated biostratigraphy provides the only means used to calibrate the geological history of the Leg 159 area, since no reliable magnetostratigraphic information is available (see Allerton, Chap. 20, this volume). The synthesized data will then be used to interpret the paleoenvironments and the sedimentary processes at work during the creation of the transform passive margin and its subsequent geologic evolution, and also to constrain the paleoceanographic history of the area during the Cretaceous.

\section{LOCATION}

Figure 1 shows the location of all sites where Cretaceous sediments were recovered during Leg 159 drilling. Site 959 is situated at a water depth of $2102 \mathrm{~m}$, on a small plateau close to the top of the CIGMR. Site 960 was drilled close to the center of the ridge on the same plateau, $3 \mathrm{nmi}(5 \mathrm{~km})$ south of Site 959, at a water depth of 2060 $\mathrm{m}$. Site 961 is located at a water depth of $3300 \mathrm{~m}$, on the last significant morphologic expression of the CIGMR just before its burial below undeformed sediments, toward the west. Site 962 is located at a water depth of $4650 \mathrm{~m}$, near the summit of a minor topographic bench extending southwest of the main CIGMR.

Comprehensive lithological, petrographical, and sedimentological descriptions of Cretaceous sedimentary sequences recovered from the holes drilled at all of these sites can be found in Mascle, Lohmann, Clift, et al. (1996). 
Figure 1. Locations of Sites 959, 960, 961, and 962.

\section{BIOSTRATIGRAPHY}

\section{Site 959}

Four holes were drilled at Site 959 of which only one (Hole 959D, Fig. 2) penetrated Cretaceous sediments. Five lithologic units were distinguished in this hole (Mascle, Lohmann, Clift, et al., 1996). Only Units V, IV, and most of Unit III belong to the Cretaceous.

\section{Lithologic Unit $V$}

This unit consists of dominant quartz sandstone interbedded with silty claystone, including terrestrial plant debris, ranging from 1081.7 to 1158.9 mbsf, Sections 159-959D-78R-CC, $20 \mathrm{~cm}$, through 71R-1, $0 \mathrm{~cm}$. The unit contains only scarce microfossils and its dating is poorly constrained. Cores 159-959D-78R through 73R, the main (and lower) part of Unit $\mathrm{V}$, are practically barren: only very rare and long-ranging pollen are found in Cores 159-959D-76R and 159959D-75R (Masure et al., Chap. 24, this volume). This barren sequence probably corresponds to continental, fluviodeltaic deposits, reminiscent of the Lower Cretaceous Bima Sandstone Formation known in the Benue Trough, Nigeria, and dated by palynomorphs as late Aptian to early Albian (Allix et al., 1981). Samples in Core 159959D-72R yield poorly to moderately preserved spore and pollen assemblages, essentially characterized by Afropollis, a genus known in Western Africa as ranging from the late Barremian to the middle Cenomanian. In addition, the absence of some other index forms, which usually co-exist with Afropollis from the middle Albian onward, suggests that the age assignment of Core 159-959D-72R can be restricted to an interval from the late Barremian to the middle Albian. This inference based on pollen would be consistent with the rare upper Aptian to middle Albian benthic foraminiferal specimens found in Core 159-959D-71R (Holbourn and Moullade, Chap. 28, this volume). However, these authors suspect some reworking processes in this interval and suggest a latest Albian to earliest Cenomanian age, based on the occurrences of rare benthic and planktonic foraminifers found as deep as Sample 159-959D-72R-1, 22-27 cm.

In summary, the biostratigraphic findings provide some evidence for (1) the occurrence of reworked late Aptian to middle Albian marine sediments deposited near Hole 959D, and (2) an in situ marine sedimentation, which cannot be directly proven, on the basis of the fossil record, before the latest Albian.

\section{Lithologic Unit IV}

Lithologic Unit IV comprises sandy limestone, sandy dolomite, calcareous sandstone, and limestone and is found from 1081.7 to 1043.3 mbsf, Sections 159-959D-70R-1, $43 \mathrm{~cm}$ through 67R-1, $0 \mathrm{~cm}$. This unit, which is separated from the underlying Unit V by an unconformity (Mascle, Lohmann, Clift, et al., 1996), was divided into two subunits: (1) Subunit IVB, from 1081.7 to $1062.7 \mathrm{mbsf}$, composed of bioclastic limestones with some sandy limestone; and (2) Subunit IVA, from 1062.7 to 1043.3 mbsf, which consists of calcareous sandstone and organic-rich claystone, including thin conglomeratic beds with phosphatic pebbles and glauconitic clasts.

A direct dating of Subunit IVB, comprised of Cores 159-959D70R and 69R, appears to be difficult since this interval was either not sampled (palynomorphs), is devoid of significant markers (foraminifers), or provides only an impoverished microfossil content (calcareous nannofossils), as a result of a marked diagenesis. The nannofossil assemblage indicates a late Albian to early Cenomanian age, according to Watkins et al. (Chap. 26, this volume). A thin section taken from Sample 159-959D-69R-1, 67-70 cm, yielded rare and poorly preserved, probably reworked, Lower Cretaceous shallow benthic foraminifers belonging to the family Orbitolinidae (M. Moullade, unpubl. data). The age of lithologic Unit IVB is also constrained by the uppermost Albian to lowermost Cenomanian beds topping Unit $\mathrm{V}$ (see above) and by the latest Cenomanian to Turonian age of most of Subunit IVA (see below).

Subunit IVA (Cores 159-959D-67R and 68R) is more reliably dated, on the basis of several groups of microfossils. Calcareous nannofossil assemblages within Core 159-959D-68R include several taxa indicative of an early Turonian age (Zone CC11; Watkins et al., Chap. 26, this volume). In the same core, black fissile shales, which have high total organic carbon (TOC) values and are intercalated within detrital limestones, contain planktonic foraminifers of the Whiteinella archeocretacea Zone (Holbourn and Kuhnt, Chap. 30, this volume), and correspond to the global oceanic anoxic "Cenomanian/Turonian Boundary Event" (CTBE, or oceanic anoxic event [OAE] 2). Unfortunately, the poor recovery at this level prevents a better and more detailed study of this critical interval. Benthic foraminifers also confirm an early Turonian age for Core 159-959D-68R. Core 159-959D-67R yielded a calcareous nannofossil assemblage indicating Subzone CC13a, of late Turonian to early Coniacian age (Watkins et al., Chap. 26, this volume). Dinoflagellates and pollen 


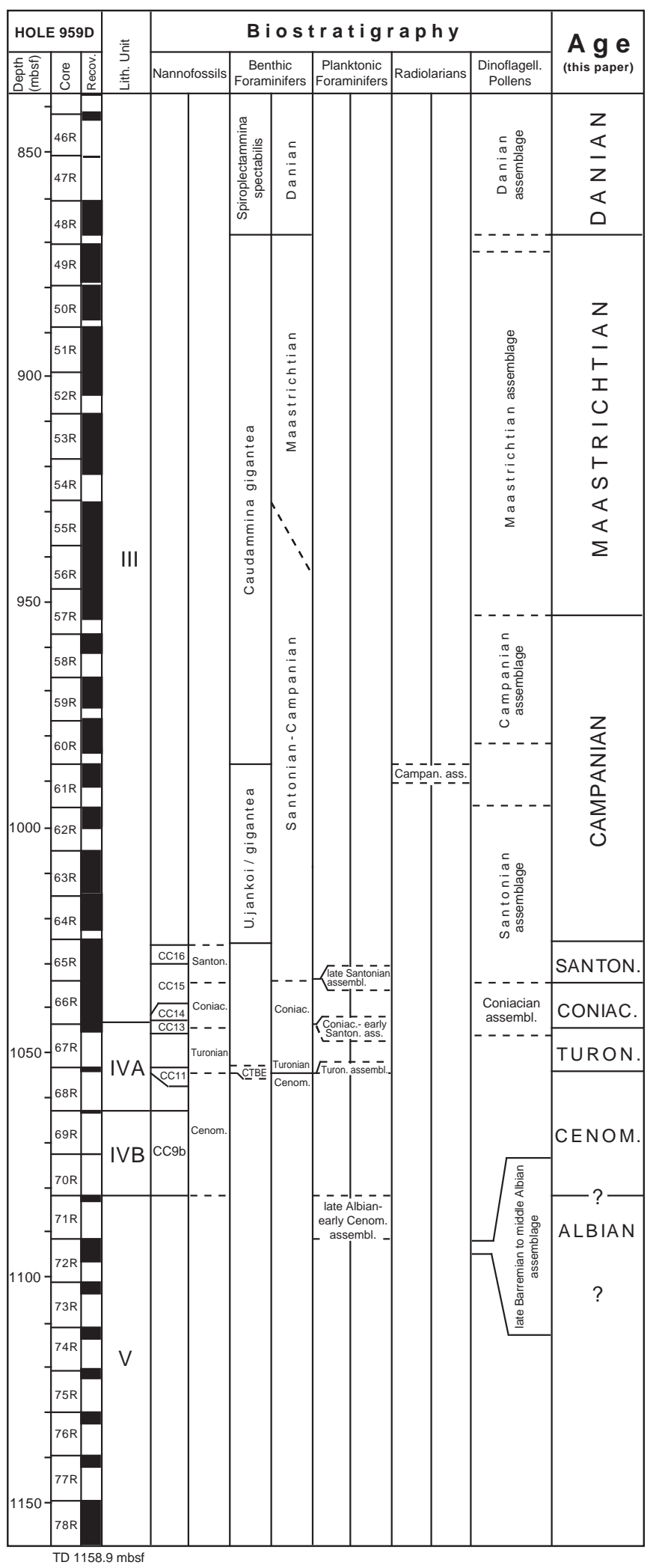

Figure 2. Multiple biostratigraphy and resulting proposed ages for the Mesozoic at Site 959 (Hole 959D).
(Oboh-Ikuenobe et al., Chap. 25; Masure et al., Chap. 24, both this volume) are less diagnostic, but do not contradict a late Cenomanian to earliest Coniacian age for Subunit IVA.

\section{Lithologic Unit III}

This unit consists of black claystone and extends from 1043.3 to 812.3 mbsf, Sections 159-959D-66R, $38 \mathrm{~cm}$, through 43R-1, $0 \mathrm{~cm}$. The lowermost portion (Core 159-959D-66R and the lower part of Core 65R) of Unit III still contains some carbonate-bearing lithologies, which yielded calcareous microfossils. Core 159-959D-66R contains a complex sequence of nannofossil claystones and phosphatic hardgrounds with at least four nannofossil subzones represented. The interval from Samples 159-959D-66R-CC, 31-33 cm, through 66R-7, 19-20 cm, is attributed to Subzone CC13b, of early Coniacian age and is separated from the overlying sequence by a prominent phosphatic hardground. Overlying the hardground, a thin $(<1 \mathrm{~m})$ interval contains calcareous nannofossil assemblages indicating Zone CC14 of middle Coniacian age. This middle Coniacian interval includes at least one horizon of phosphatic conglomerate, presumably derived from the local erosion of a phosphatic hardground, and is bounded at its top by a thin phosphatic hardground/pebble bed. Overlying this is a thin $(<1 \mathrm{~m})$ interval of nannofossil claystone, characterized by alternating laminated and non-laminated horizons on a decimeter scale, which contains an assemblage attributed to Subzone CC15a of late Coniacian age. The interval from Sample 159-959D66R-5, 8-9 cm through 65R-3, 89-91 cm, which also exhibits an irregular alternation of laminated and non-laminated horizons, contains an assemblage indicating Subzone CC15b of late Coniacian to early Santonian age. Near the top of the nannofossil claystone interval (in Section 159-959D-65R-3), pelagic carbonate becomes progressively rare, and increased etching of the calcareous nannofossils occurs. These last carbonate-bearing beds can be attributed to Zone CC16, of late (but not latest) Santonian age, on the basis of the calibration of the calcareous nannofossil biostratigraphic scales.

The nannofossil-based ages are more or less consistent with those derived from the other groups of microfossils. Sample 159-959D66R-CC contains a planktonic foraminiferal assemblage of a Coniacian to early Santonian age (Bellier, Chap. 27, this volume), instead of a middle Coniacian age as based on nannofossils. Sample 159959D-65R-06, 28-32 cm, contains the planktonic foraminifer Dicarinella asymmetrica (Kuhnt et al., Chap. 31, this volume), a zonal marker for the late Santonian, whereas these beds are regarded as early Santonian according to their nannofossil content. Core 159959D-66R and Sections 159-959D-65R-7 to 65R-5 yield nondiagnostic Upper Cretaceous calcareous benthic foraminifers. On the basis of dinoflagellates, Oboh-Ikuenobe et al. (Chap. 25, this volume) suggest the placement of the Coniacian/Santonian boundary in Sample 159-959D-65R-6, 10-13 cm, an assignment that fits better (but not perfectly) with nannofossil than with planktonic foraminiferal data. As a result, the final age assignments proposed in this paper (Fig. 2) for these middle-Cretaceous levels reflect the best possible compromise between the various age determinations from different microfossil groups.

The biostratigraphic subdivision of the upper part of Unit III (Cores 159-959D-64R to 49R) is more problematic since these beds are entirely devoid of calcareous microfossils. However, the initial shipboard subdivisions, based only on palynomorphs, have been strengthened by shore-based studies on deep-water noncalcareous benthic foraminifers and additional investigations on pollen, dinoflagellates, and, to a lesser extent, radiolarians.

According to Oboh-Ikuenobe et al. (Chap. 25, this volume), the Santonian/Campanian boundary is placed in Sample 159-959D-62R$1,21-24 \mathrm{~cm}$, on the basis of the marker Odontochitina porifera. This assumes that the only occurrence of this species in this sample corre- 
sponds to its LO (lowest occurrence). The composition of the microflora provides additional arguments leading to the definite assignment of an early Campanian age to the interval between Samples 159-959D-60R-4, 94-96 cm, and 60R-2, 100-104 cm. A problem of uncertain stratigraphic distribution also arises with the agglutinated benthic foraminifers: Kuhnt et al. (Chap. 31, this volume) interpret the single occurrence of the Turonian to mid-Campanian marker Uvigerinammina jankoi in Sample 159-959D-61R-02, 61-65 cm, as its HO (highest occurrence). However, they also assume that a biosiliceous, radiolarian-rich interval observed in Sections 159-959D-61R1 to 3 and in which Erbacher (Chap. 29, this volume) briefly mentions a radiolarian fauna of Campanian age, may correspond to the early Campanian paleoceanographic event observed in the North Atlantic and western Tethys (Kuhnt, 1992). This event was correlated within the Gubbio section (northern Italy) with the upper part of the A34 magnetic reverse zone, which roughly corresponds to the early Campanian. The stratigraphic attribution of the sequence comprised of Cores $159-958 \mathrm{D}-61 \mathrm{R}$ and $60 \mathrm{R}$ to the early Campanian is also strengthened by the first occurrence of the agglutinated benthic foraminiferal species Rzehakina epigona (Section 159-958D-60R-5) and Hormosina velascoensis (Section 159-958D-60R-2). The age assignments mentioned above are also approximately consistent with the conclusions of the shore-based group of palynologists (Masure et al., Chap. 24, this volume). They report the first occurrence of some members of the Andalusiella group and Trichodinium castanea ssp. bifidum in Section 159-959D-60R-4, which suggests a Campanian age. However, the first forms of the genus Rzehakina already occur in the upper part of Core 159-959D-65R and the Santonian/Campanian boundary was placed in Section 159-959D-65R-1 by Kuhnt et al. (Chap. 31, this volume). As a result, the Santonian/Campanian boundary is tentatively placed in Section 159-959D-65R-1, according to benthic foraminifers.

The position of the Campanian/Maastrichtian boundary at Site 959 is relatively well constrained. There is some agreement between palynologists, although on the basis of different markers. ObohIkuenobe et al. (Chap. 25, this volume) dated as late Campanian Sample 159-959D-58R-1, 2-5 cm, and as early Maastrichtian Sample 57R-1, 31-34 cm. Masure et al. (Chap. 24, this volume) consider Section 159-959D-58R-3 to be late Campanian in age, and the appearance of four diagnostic species in Section 57R-4 argues for a Maastrichtian age. The benthic foraminiferal record does not provide any significant argument to delineate this boundary more accurately. Kuhnt et al. (Chap. 31, this volume) placed the boundary within an interval including Core 159-959D-55R and the upper part of Core 56R. The Campanian/Maastrichtian boundary (between Sections 159-959D-58R-1 and 57R-4) based on palynomorphs (i.e., as old as Section 57R-4) is retained in this paper.

The placement of the Cretaceous/Tertiary boundary at Site 959 is based only on palynomorph and benthic foraminiferal distribution. According to Oboh-Ikuenobe et al. (Chap. 25, this volume), the Maastrichtian/Danian boundary lies between Sample 159-959D49R-4, 99-102 cm, and Sample 159-959D-48R-5, 37-41 cm, on the basis of the FO of Spiniferites septatus, Fibrocysta bipolaris, F. vectensis, and the absence of typical Maastrichtian species such as Dinogymnium spp. and Perceites pentagona. Additionally, the authors observed the first occurrence of Cyclapophysis monmouthensis in Sample 159-959D-51R-2, 55-57 cm, and Riculacysta amplexus in Sample 49R-4, 99-102 cm. The FAD (first appearance datum) of these species is known to occur in the late Maastrichtian (Kirsch, 1991; Firth, 1993).

On the basis of the study of a different set of samples, Masure et al. (Chap. 24, this volume) suggest the placement of the Cretaceous/ Tertiary $(\mathrm{K} / \mathrm{T})$ boundary in Sample 159-959D-52R-3, 10-13 cm, about $35 \mathrm{~m}$ below that defined by Oboh-Ikuenobe et al. (Chap. 25, this volume). To delineate the boundary, Masure et al. (Chap. 24, this volume) used the first occurrence of Damassadinium californicum (a species not found by Oboh-Ikuenobe et al.) and the fact that they did not observe any species of the genus Dinogymnium above Sample 159-959D-54R-2, 97-99 cm. Damassadinium californicum is used as a marker for the basal Danian in Europe (Hansen, 1977, 1979a, $1979 b$ ) in Tunisia (Brinkhuis and Zachariasse, 1988), in Alabama (Habib et al., 1992), and even on a worldwide scale (Haq et al., 1987). The other species of the genus are restricted to the PaleoceneEocene, with the exception of Damassadinium chabanis (AptianAlbian) and D. fibrosa (latest Maastrichtian in southern Scandinavia).

The divergence in palynological dating may be explained by the sampling of different intervals resulting in different fossil findings, a possible diachronism between mid- and low-latitude distributions, and also by the fact that the stratigraphic ranges of these dinoflagellate cysts are still poorly calibrated in the equatorial realm.

Applying a deep-water benthic agglutinated foraminiferal zonation calibrated in the North Atlantic and western Tethys (Geroch and Nowak, 1984; Moullade et al., 1988) to Site 959, Kuhnt et al. (Chap. 31 , this volume) placed the K/T boundary between Sample 159959D-48R-6, 28-31 cm (last occurrence of Caudammina gigantea, marker for the middle Campanian to Maastrichtian $C$. gigantea Zone), and Sample 159-959D-48R-5, 28-31 cm, where a distinct acme of the Paleogene cosmopolitan form Spiroplectammina spectabilis begins. Such a placement of the K/T boundary is consistent with the proposal of Oboh-Ikuenobe et al. (Chap. 25, this volume).

It is interesting to note that a remarkable increase and a subsequent sharp drop in the abundance of kaolinite has been noted by Pletsch et al. (1996) in samples from Cores 159-959D-49R through 48R. The peak abundance occurs in Section 159-959D-49R-4, some seven $\mathrm{m}$ below the proposed $\mathrm{K} / \mathrm{T}$ boundary interval. Similar increases in relative kaolinite contents at the $\mathrm{K} / \mathrm{T}$ boundary were described from several other West African, North American, and South European localities (e.g., Chamley et al., 1988; Pollastro and Pillmore, 1987; Deconinck, 1992; Ortega-Huertas et al., 1995). On the basis of all these arguments, the placement between Sections 159-959D-48R6 and 48R-5 is retained in this paper for the K/T boundary.

\section{Site 960}

Site 960 , located only $3 \mathrm{nmi}$ south of and in approximately the same water depth as Site 959, was selected as a backup site for the structurally deep target (Seismic Units A and B), shown there to be possibly more accessible because of the pinching out of the overlying units (Mascle et al., 1988). Three holes were drilled, of which only two (Holes 960A and 960C; Fig. 3) penetrated Cretaceous sediments (lithologic Units V and IV; Mascle, Lohmann, Clift, et al., 1996).

\section{Lithologic Unit $V$}

Lithologic Unit V was recovered only in Hole 960A, from 451.2 in Core 159-960-61R-CC, $4 \mathrm{~cm}$, TD (total depth) to $329 \mathrm{mbsf}$ in Core 159-960-37R-1, $45 \mathrm{~cm}$. As in Site 959, this unit is characterized by the dominance of siliciclastic sediments: silty sandstone, siltstone, and clayey siltstone in Subunit VB, quartz sandstone and siltstone in Subunit VA. Unit V is separated from the overlying unit by a sharp boundary, which was inferred to be an unconformity, based on the abrupt change in lithofacies, the inclusions within Unit IV of lithoclasts derived from erosion of the underlying sandstones and claystones, and the abrupt downhole increase in bedding dips (Mascle, Lohmann, Clift, et al., 1996). Unit V was found to be completely devoid of calcareous microfossils and only yielded rare and often poorly preserved palynomorphs. According to Oboh-Ikuenobe et al. (Chap. 25, this volume), the lowermost sample from Subunit VB (159-960A-61R-1, 19-21 cm; 446.39 mbsf) contains the bisaccate pollen Parvisaccites sp. (cf. P. radiatus), which is common in Aptian to Cenomanian sediments. Masure et al. (Chap. 24, this volume) 


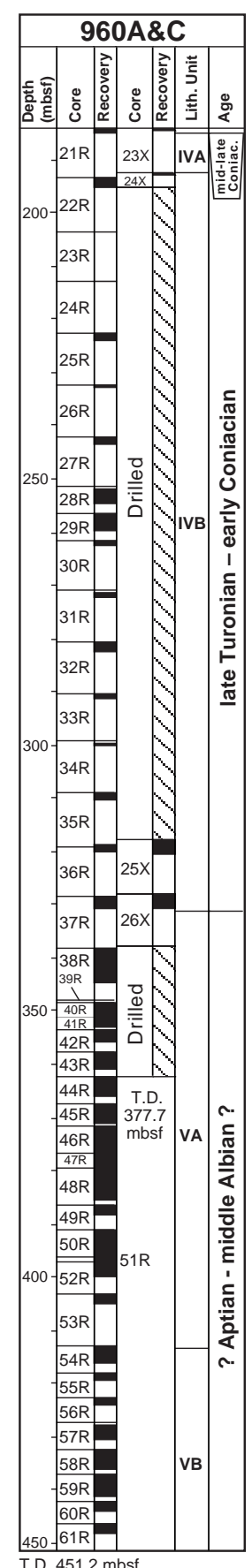

Figure 3. Chronostratigraphic interpretation of the Mesozoic at Site 960 (Holes 960A and 960C).

found the same spore and pollen assemblage throughout Unit V, characterized by Afropollis sp., which leads to the same age assignment as Unit V in Hole 959D, that is, late Barremian to middle Albian. Thus, on the basis of the palynomorph content, an Aptian to middle Albian age is suggested for Unit V at Site 960.

\section{Lithologic Unit IV}

This unit was drilled twice (Hole 960A, with continuous coring, and Hole 960C, with spot coring). The unit consists of (1) quartz sand limestone, intraclast/skeletal grainstone/packstone, and bioclastic organic-rich claystone (Subunit IVB, thickness $\sim 145 \mathrm{~m}$ ); the skeletal grains include bivalve, echinoderm, stromatoporoid, and calcareous algal debris; (2) micrite claystone, biogenic phosphate, and glauconite grainstone (Subunit IVA, thickness $\sim 10 \mathrm{~m}$ ).

On the basis of sparse and poorly preserved calcareous nannofossils, Watkins et al. (Chap. 26, this volume) dated the base of Subunit IVB as late Turonian (Sample 159-960C-26X-CC) to early Coniacian (Sections 159-960C-26X-1 and 26X-2). This is consistent with the occurrence in the same core (Samples 159-960C-26X-CC and 159-960C-26X-2, 25-28 cm) of Turonian planktonic foraminifers (Bellier, Chap. 27, this volume). The Late Cretaceous age suggested by long-ranging palynomorphs found in Cores 159-960C-26X and 24X (Masure et al., Chap. 24, this volume) does not help to constrain the assignment of the upper part of this subunit. However, at the base of the overlying Subunit IVA (Sample 159-960C-23X-CC), a middle Coniacian calcareous nannofossil assemblage was found (Watkins et al., Chap. 26, this volume). This leads to the assumption that Subunit IVB covers a late Turonian to early Coniacian timespan.

The top of Subunit IVA (Sample 159-960A-20R-CC) is represented by a thin $(>1 \mathrm{~cm})$ phosphatic hardground crust, which provided a calcareous nannofossil assemblage diagnostic for Subzone CC15a of late Coniacian age (Watkins et al., Chap. 26, this volume). In Hole 960A, this crust is disconformably overlain by palygorskitic claystone of early Eocene age.

It is interesting to note that above lithologic Unit V, which is very similar at Sites 959 and 960, there are important lithologic and/or chronologic divergences, although Sites 959 and 960 are very close in location. Subunit IVB, which consists of dominantly bioclastic material at both sites, is $20 \mathrm{~m}$ thick and is of (early) Cenomanian age at Site 959, whereas it is $145 \mathrm{~m}$ thick and of late Turonian to early Coniacian age at Site 960. The phosphatic beds of Subunit IVA are dated late Cenomanian to earliest Coniacian at Site 959, and middle to late Coniacian at Site 960. Finally, the remaining part (post-Coniacian) of the Upper Cretaceous, which is represented by thick, deepwater deposits at Site 959, is missing at Site 960.

\section{Site 961}

Two holes were drilled and three lithologic units were identified at Site 961 (Fig. 4). Only Unit III, which consists of siliciclastic deposits and was tentatively correlated with the upper part of Unit V of Sites 959 and 960 (Mascle, Lohmann, Clift, et al., 1996), probably belongs to the Cretaceous. Rare and very poorly preserved specimens of dissolution-resistant long-ranging (Bajocian to Maastrichtian) Mesozoic calcareous nannofossils were found in Samples 159-961-11RCC and 9R-CC (Mascle, Lohmann, Clift, et al., 1996). All Unit III samples from Site 961, which were analyzed during shipboard investigations, were barren of dinoflagellate cysts and contained only specimens of pollen, common in Aptian to Cenomanian sediments (Oboh-Ikuenobe et al., Chap. 25, this volume). These are thought to correspond (Masure et al., Chap. 24, this volume) to middle Albian assemblages found in the Ivory Coast and in Brazil by various authors. This dating is consistent with the late Barremian to middle Albian age attributed (see above) to the correlative units at Sites 959 and 960. In Hole 961A, sediments of Unit III are directly overlain by chert, palygorskite claystone, and porcellanite of late Paleocene to early Eocene age.

\section{Site 962}

Four holes were drilled at Site 962. Cretaceous sediments (lithologic Unit III and Subunits IIC and IIB) were reached in Hole 962C and penetrated in Hole 962B and 962D (Fig. 5). 


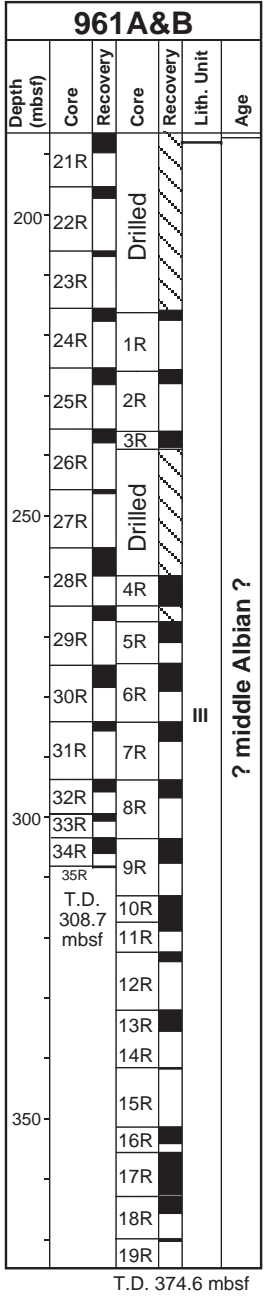

Figure 4. Chronostratigraphic interpretation of the Mesozoic at Site 961 (Holes 961A and 961B).

\section{Lithologic Unit III}

This unit is $270 \mathrm{~m}$ thick and is restricted to Hole 962D from Core 159-962D-37R to Section 159-962D-6R-1, $7 \mathrm{~cm}$. The unit comprises limestone with quartz sand and silt, calcareous sandstone, clayey siltstone, and claystone. This sequence appeared to be strongly disturbed by tectonics (Mascle, Lohmann, Clift, et al., 1996). Calcareous nannofossils indicating Subzone CC9b (late Albian to earliest Cenomanian) are found throughout the sequence (Watkins et al., Chap. 26, this volume). According to Bellier (Chap. 27, this volume) planktonic foraminifers observed in the same beds suggest a latest Albian age, whereas according to Holbourn and Moullade (Chap. 28, this volume) planktonic and benthic foraminiferal composite assemblages indicate (1) a permanent in situ latest Albian to earliest Cenomanian component; and (2) intermittent late early to late (but not latest) Albian allochthonous components. The dinoflagellate cysts are not age diagnostic according to Oboh-Ikuenobe et al. (Chap. 25, this volume), but considered as Cenomanian in age by Masure et al. (Chap. 24, this volume). On the other hand, Oboh-Ikuenobe et al. conclude that the sporomorph data support the late Albian (late Albian-earliest Cenomanian, in fact) age assigned to this interval on the basis of calcareous nannofossils, whereas Masure et al., on the basis of the co-occurrence of Triorites africaensis and Classopollis brasil-

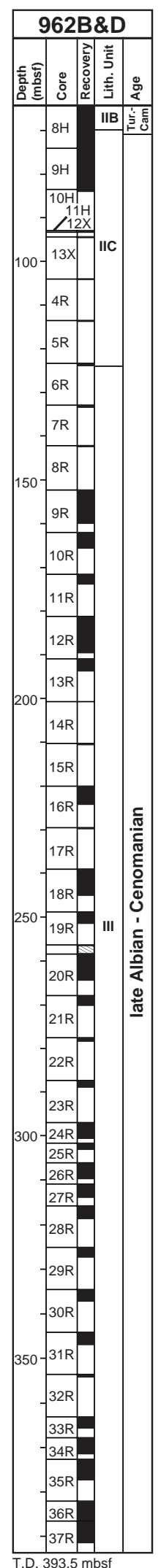

Figure 5. Chronostratigraphic interpretation of the Mesozoic at Site 962 (Holes 962B and 962D). 
iensis, indicate an age close to the early/late Cenomanian boundary. Thus, lithologic Unit III at Site 962 is chronologically correlatable (at least partly) with Unit V at Sites 959 and 960.

\section{Lithologic Subunit IIC}

This subunit, which was drilled three times with poor recovery, consists of chert and porcellanite with minor interbedded clay.

In Hole 962B, this subunit was defined from Sections 159-962B13X-CC, $18 \mathrm{~cm}$ (TD) through 8H-4, $90 \mathrm{~cm}$ (Mascle, Lohmann, Clift, et al., 1996). Samples from Core 159-962B-10H contain a calcareous nannofossil assemblage diagnostic for Subzone CC9c of early Cenomanian age (Watkins et al., Chap. 26, this volume). In Sample 159962B-10H-CC, Bellier (Chap. 27, this volume) found planktonic foraminifers of late Albian age. On the basis of planktonic and a few benthic foraminifers, Holbourn and Moullade (Chap. 28, this volume) suggested a late Albian-earliest Cenomanian age for Section 159-962B-9H-4 and a slightly younger (Cenomanian?) age for Sections $159-962 \mathrm{~B}-8 \mathrm{H}-\mathrm{CC}$ to $8 \mathrm{H}-5$. A more precise dating is given on the basis of radiolarians (Erbacher, Chap. 29, this volume). These siliceous microfossils have been found in Subunit IIC from Cores 159$962 \mathrm{~B}-10 \mathrm{H}$ to $8 \mathrm{H}$ in two distinct intervals: (1) from Sections 159962B-10H-CC to $9 \mathrm{H}-1$, indicating the middle part of the upper Albian; and (2) from Sections 159-962B-8H-CC to 8H-4, $65 \mathrm{~cm}$, suggesting a middle to late Cenomanian age.

The ages based on palynomorphs appear to be less precise than those based on calcareous microfossils and radiolarians. However, on the basis of spores and pollen grains, Masure et al. (Chap. 24, this volume) have given Cores 159-962B-9H and $8 \mathrm{H}$ an age straddling the early/late Cenomanian boundary. This assignment, at least as far as Core 159-962B-8H is concerned, is rather consistent with the age based on radiolarians. On the other hand, Oboh-Ikuenobe et al. (Chap. 25, this volume) helped to biostratigraphically constrain the base of Subunit IIC in Hole 962B, with the finding in Sample 159962B-13X-CC of dinoflagellate cysts indicating an age not older than late Albian.

In Hole 962C, long-ranging planktonic foraminifers found only in Sample 159-962C-3R-CC (TD) by Bellier (Chap. 27, this volume) indicate a late Albian to early Coniacian age.

In Hole 962D, the calcareous nannofossils, found only in the lower part of Subunit IIC, though less well preserved than in Unit III, seem to indicate the same early Cenomanian age (Watkins et al., Chap. 26, this volume). This interval is barren of foraminifers and was not sampled for palynomorphs.

In summary, Subunit IIC is given a late Albian to early-late (but not latest) Cenomanian age, mainly on the basis of the biostratigraphic findings from Hole 962B.

\section{Lithologic Subunit IIB}

This subunit was drilled in Hole 962B (from Sections 159-962B$8 \mathrm{H}-4,90 \mathrm{~cm}$ through $8 \mathrm{H}-1,0 \mathrm{~cm}$ ) and Core $159-962 \mathrm{C}-1 \mathrm{R}$, and it consists of palygorskite claystone. In Hole 962B, its delimitation from the underlying subunit, occurring in a disturbed sequence, is questionable, and its dating is poorly constrained: the radiolarian assemblages found in a short interval $(2-28 \mathrm{~cm})$ in Section $159-962 \mathrm{~B}-8 \mathrm{H}-$ 4 are tentatively placed into the Coniacian/Santonian by Erbacher (Chap. 29, this volume).

\section{PALEOENVIRONMENTS} Site 959

In lithologic Unit $\mathrm{V}$, the lowest marine microfossil occurrence is in Section 159-959D-72R-3, which is probably of late Albian age.
Below this level, only very rare and poorly preserved spores, pollen, and abundant wood fragments were found and most samples were, in fact, barren. The palynofacies of Unit V is dominated by terrestrially derived organic-matter particles and amorphous organic matter (AOM) of terrestrial origin. Dinoflagellate cysts and microforaminiferal linings are absent. All these features might suggest either proximity to the paleoshoreline, or even a continental environment of deposition. However, according to Oboh-Ikuenobe et al., (Chap. 25, this volume) and to Masure et al. (Chap. 24, this volume), the organic components of the lowermost cores of Unit $\mathrm{V}$ indicate an overmature thermal stage. Therefore, the absence of any kind of identifiable microfossils in these sediments is probably a result of oxidation and/or thermal degradation. The possibility of a biased fossil record prevents any decisive interpretation of the depositional environment for this sequence.

Reworking of rare upper Aptian to lower Albian calcareous benthic foraminifers in upper Albian beds (Holbourn and Moullade, Chap. 28, this volume) provides evidence that marine sedimentation began in the vicinity of Hole 959D as early as this age. The impoverished in situ foraminiferal assemblages found in Core 159-959D-71R do not permit a paleobathymetric interpretation based on quantitative data, although the rarely observed taxa point to a mid/outer shelf environment. This hypothesis is consistent with the data from palynofacies studies (Oboh-Ikuenobe et al., Chap. 25, this volume), which suggest middle-shelf paleodepths for Unit V.

The synthesis of the paleoenvironmental interpretation of the Cenomanian-Turonian Unit IV is difficult because of (1) very low recovery; and (2) the presence of hiatuses and/or condensed intervals. On the basis of the nannofossil record, Watkins et al. (Chap. 26, this volume) assume that the middle and upper Cenomanian are missing at Site 959. Thus, lower Turonian sandy limestone with phosphate hardgrounds and pebbles directly overlies lower Cenomanian (CC9b Subzone) detrital limestones, consisting of displaced neritic components and interpreted as hemipelagic sediments. The allochthonous character of the bioclasts is confirmed by M. Moullade (unpubl. data). This is consistent with the results of Oboh-Ikuenobe et al. (Chap. 25, this volume), which show that Unit IV is richer in marine AOM than Unit V, indicating a more distal location for the source material.

The paleoenvironmental interpretation of the Turonian part of Subunit IVA is better constrained, both by TOC measurements and quantitative analyses of its benthic foraminiferal content (Holbourn and Kuhnt, Chap. 30, this volume). In Core 159-959D-68R (early Turonian), the low diversity and strong dominance of buliminids and bolivinids in the assemblage, together with the relatively high TOC values, suggest poorly oxygenated bottom waters in an outer shelf or upper slope setting. In Core 159-959D-67R (late Turonian to early Coniacian), the low-abundance and low-diversity assemblage includes organically cemented agglutinated taxa and corroded tests of calcareous benthic foraminifers. This, together with the high sand content of the sediment, may reflect either a deepening trend or, more likely, an episode of increased terrigenous sedimentation when the oxygen minimum zone shifted further out into the basin. Clay minerals (Pletsch et al., 1996) from Unit IV indicate a mixed input of finegrained sediment from soils and rapidly eroding rock substrates. This suggests that one or several terrestrial sources existed close to Site 959 until at least the late Turonian.

The paleobathymetry of the deposits recovered at the base of Unit III (Core 159-959D-66R and Sections 159-959D-65R-7 to 65R-5, middle Coniacian to early Santonian) is comparable to that of Core 159-959D-68R, based on its benthic foraminiferal content (Holbourn and Kuhnt, Chap. 30, this volume). The variations in assemblage composition and high TOC values suggest that oxygen minima were established on the outer shelf or upper slope, with periodic contraction or expansion of the oxygen minimum zone. An increase in paleo- 
depth is indicated in Section 159-959D-66R-1 with the appearance of a few deep-water agglutinated foraminifers (DWAF). A considerable increase in the proportion of DWAF is then observed in Sample 159959D-65R-5, 30-34 cm (early Santonian).

There is a marked change in clay-mineral assemblages between lithologic Units IV and III. Minerals indicating rapid (physical) erosion of rock substrates are completely absent from Core 159-959D67R upsection (Pletsch et al., 1996). This may be the result of the drowning of terrestrial source areas in the vicinity of Site 959 after the Turonian.

Above Sample 159-959D-65R-5, 30-34 cm, the remaining Upper Cretaceous sequence (Cores 159-959D-65R to 49R) contains mainly DWAF with organic cement (Kuhnt et al., Chap. 31, this volume). The sudden increase in the proportion of DWAF in the early Santonian and the disappearance of all calcareous taxa in Core 159-959D64R suggest a rapid deepening below the CCD. An increasing water depth since the early Campanian is deduced from the increasing diversity of the agglutinated assemblages and from a successive increase upsection in the abundance of typical deep bathyal-abyssal species, indicative of a water depth of at least 2500-3000 m (Kuhnt et al., Chap. 31, this volume).

Two significant global paleoceanographic events are also recorded in the Cretaceous sediments from Site 959. The anoxic Cenomanian/Turonian Boundary Event (CTBE) is registered in black fissile shales with high TOC values intercalated within Core 159-959D68R, which contains planktonic foraminifers of the W. archeocretacea Zone. The Lower Campanian Event (LCE), corresponding to a very prominent interval of biosiliceous sedimentation, is observed within Cores 159-959D-63R to 61R. Microfossil assemblages within this interval are characterized by poorly preserved agglutinated foraminifers and abundant radiolarians. A similar lower Campanian radiolarian-rich interval, with comparable changes in assemblage composition of benthic foraminifers, has been observed in the North Atlantic and in the Tethys (Kuhnt et al., Chap. 31, this volume). The record at Site 959 provides the first indications of the occurrence of this event in the Equatorial Atlantic, which suggests that a deep-water circulation system was already well established between the North and South Atlantic at this time.

In addition to the biogenic silica content, there is abundant claysized quartz in sediments of Cores 159-959D-64R through 50R. Although part of the quartz may be of diagenetic origin (Marcano et al., Chap. 8, this volume), the lack of diagenetic structures and the high microporosity of the claystones of Unit III, observed under the scanning electron microscope (SEM), argue for a sedimentary origin of the fine-grained quartz (T. Pletsch, unpubl. data). Its association with abundant smectite and the scarcity or complete lack of kaolinite, suggests supply from arid or semi-arid sources, possibly via aeolian transport.

The sharp increase and subsequent drop in kaolinite around the K/ $\mathrm{T}$ boundary may result from a deterioration in continental climate at, or just before, the K/T event. Alternatively, increasing kaolinite may result from a lowering sea level and concurrent erosion of low-lying coastal areas. Unfortunately, the lack of a high-resolution time control at Site 959 does not allow one to precisely correlate this claymineral event with similar events at other places in the world, and thus to determine whether it is related to the regression that preceded the $\mathrm{K} / \mathrm{T}$ boundary or to the $\mathrm{K} / \mathrm{T}$ event itself.

\section{Site 960}

The absence of foraminifers and calcareous nannofossils throughout Unit $\mathrm{V}$ is in agreement with the paleoenvironmental interpretation of lacustrine sediments for lithologic Subunit VB, and of brackish marine deposits for Subunit VA (Mascle, Lohmann, Clift, et al., 1996). Palynological evidence also supports this interpretation as spores and pollen are only recovered from Subunit VB, and rare, poorly preserved dinoflagellates from Subunit VA (Masure et al., Chap. 24, this volume; Oboh-Ikuenobe et al., Chap. 25, this volume).

The neritic coarse components of the late Turonian-early Coniacian Subunit IVB were interpreted as allochthonous deposits of shallow-water material transported into deeper marine settings (Mascle, Lohmann, Clift, et al., 1996). Further shore-based studies (Watkins et al., Chap. 26, this volume; T. Pletsch, unpubl. data; M. Moullade, unpubl. data) entirely confirm such an interpretation.

Cenomanian through early Santonian paleoenvironments at Sites 959 and 960 differ significantly despite their geographic proximity. This sequence at Site 959 consists of less than $30 \mathrm{~m}$ of fine-grained sandy limestone and claystone, and contains common phosphatic debris, including several distinct hardgrounds. Calculated accumulation rates vary from 6 to $2.5 \mathrm{~mm} / \mathrm{yr}$ (Watkins et al., Chap. 26, this volume). At nearby Site 960, the correlative Turonian through Coniacian section is globally at least four times thicker than the condensed interval at Site 959. Condensation at this latter site might even be stronger in discrete intervals (see Watkins et al., Chap. 26, this volume, for a detailed analysis). The sediment at Site 960 is globally coarser in texture (grainstones and packstones), and contains large neritic invertebrate skeletal debris. Site 960 appears to have been the depocenter for transported material from a nearby carbonate shelf while Site 959 (located less than $3 \mathrm{nmi}$ downslope) was sediment starved. After the Coniacian, Site 960 deposits (of unknown nature) were subjected to erosion before the Eocene, whereas Site 959 was affected by a rapid deepening and continuous deep-water sedimentation.

\section{Site 962}

Site 962 , situated approximately $50 \mathrm{~km}$ away from Site 959 , provides an insight into the Cretaceous paleoenvironment of the neighboring area at greater present water depths. Upper Albian deposits from Site 962 are more marine than those at Site 959 and indicate a deeper (outer-shelf to upper-bathyal) setting (Holbourn and Moullade, Chap. 28, this volume). However, these authors noted some evidence of transport, sorting, and redeposition of allochthonous faunal components from the middle or inner shelf. This is indicative of a varied paleotopography close to or on the ridge itself. The increasing dissolution of calcareous microfaunas upsection in the upper part of Unit III and in Subunit IIC could be interpreted as evidence of rapid deepening during the Cenomanian at Site 962. However, Holbourn and Moullade suggested that the increase in dissolution, associated with radiolarian-rich intervals, pointed to dysoxia, resulting from an increase in surface-water fertility. The hypothesis of an upper Albian high level of surface-water fertility was also proposed by Watkins et al. (Chap. 26, this volume), based on the composition of calcareous nannofossil assemblages. According to Erbacher (Chap. 29, this volume), the radiolarian-rich intervals correspond to transgressive episodes, which are the immediate precursors of global oceanic anoxic events (OAEs). Three main events are registered at Site 962: in the late Albian, (pre-OAE ld), in the late Cenomanian (pre-OAE 2), and in the Campanian (OAE 3).

\section{PALEOBIOGEOGRAPHY}

During the Early Cretaceous, the continental margins on both sides of the Equatorial Atlantic were affected by the lateral movements of the African and South American plates, which started to slide the two areas past each other (Mascle et al., 1988). At this time, the nascent Equatorial Atlantic became the site of an open marine connection between the Central Atlantic and the South Atlantic. Before drilling Leg 159, the existence of such a marine link was mainly inferred from indirect evidence based on paleobiogeographic comparisons between Tethyan and South Atlantic faunas: ammonites (Wiedmann and Neugebauer, 1978; Förster, 1978), and foraminifers 
(Moullade and Guérin, 1982), which provided evidence that an open seaway was plausible as early as the middle Albian. This hypothesis was further strengthened by the recovery of sediments containing middle Albian bathypelagic foraminifers in cores drilled along the slope of the southern Guinean Plateau (Moullade et al., 1993). More to the west, Bonatti et al. (1996) found deep-water carbonates as old as Berriasian in dredges from the intersection between the Romanche Fracture Zone and the Mid-Atlantic Ridge. Therefore, the findings in Hole 959D of (even though reworked) marine upper Aptian to middle Albian "Tethyan" foraminifers (Holbourn and Moullade, Chap. 28, this volume) confirm these previous studies. However, significant numbers of Albian (Holbourn and Moullade, Chap. 28, this volume) and lower Turonian to lower Coniacian (Holbourn and Kuhnt, Chap. 30 , this volume) endemic benthic foraminifers indicate that, after the opening of the seaway, the mid-Cretaceous submarine topography in the CIGMR area must have remained fragmented and circulation restricted. The wider biogeographic distribution during the middle Coniacian to early Santonian provides evidence for more open connections between Equatorial Atlantic basins. The occurrence of cosmopolitan taxa in the more diversified assemblages from Core 159959D-66 R and the abundance of deep-water agglutinated benthic foraminifers in Sample 159-959D-65R-5, 30-34 cm also demonstrate that deep circulation was well established between the North and South Atlantic by the late Coniacian-early Santonian.

\section{CONCLUSION}

The synthesis of biostratigraphic, paleoenvironmental, and paleobiogeographic data presented above helps to reconstruct more accurately the Cretaceous paleoceanographic evolution of the CIGMR.

The oldest sedimentary unit drilled at the four sites consists of a siliciclastic formation, which was tectonically deformed and subjected to local erosion, and is separated from the overlying units by an unconformity. At Sites 959, 960, and 961 this unit appears to be wholly or partly (pro parte maxima) nonmarine. The observed continental and transitional marine succession ranges from the Aptian to the middle Albian. At Site 959, the uppermost part of the unit is clearly marine, dated as late Albian, and already corresponds to a midshelf environment. At Site 962 the correlative unit is of late Albian to earliest Cenomanian age and represents a more open-marine environment with paleodepths around $200 \mathrm{~m}$. The degree of uncertainty in the age assignment does not allow a more precise spatial and temporal resolution of the deposition patterns on a regional scale.

At Site 959 thin bioclastic sediments were deposited from the early Cenomanian. They were interpreted (Mascle, Lohmann, Clift, et al., 1996) as evidence for the hemipelagic disintegration of a reefal environment situated near the top of the ridge of the CIGMR. In fact, our observations suggest that, rather than a reefal facies, these are shallow, inner-shelf deposits without typical reef-building organisms, which nevertheless indicate that the ridge and its immediate surroundings had a diversified paleotopography. A predominantly biosiliceous sedimentation occurred at the same time at the more distal and deeper Site 962. This interval is rich in radiolarians, indicators of high surface-water productivity and of transgressive episodes that are immediate precursors of global anoxic events.

The Turonian-Coniacian at Site 959 corresponds to a period when the oxygen minimum zone strongly affected the outer shelf and upper slope and led to the deposition of condensed intervals with phosphatic levels. At the same time Site 960, although very close, was the site of a thick, coarse and dominantly bioclastic sedimentation. These deposits can be interpreted as being produced by the dismantling and redeposition, in an already deep setting, of a neritic inner shelf (rather than typically reefal) biofacies. The thick deposits at Site 960 contrast markedly with the condensed coeval sediments observed at Site 959. It is difficult to interpret the contemporaneous sedimentation at Site
962 , since no precise dating of this age is available from the carbonate-free claystone.

From the Santonian onward, a more rapid subsidence occurred at Site 959, where sub-CCD lower bathyal to abyssal depths of at least 2500 to $3000 \mathrm{~m}$ were attained. A last Cretaceous global biosiliceous paleoceanographic event (LCE, which corresponds to OAE 3 ) is registered in the early Campanian. The absence of deposits following erosion prevents any insight into the contemporaneous sedimentation at Site 960 . A possible precursor of the LCE is furtively registered at Site 962 by a thin radiolarian-rich interval.

The K/T boundary event, which is difficult to locate precisely at Site 959 on account of diverging biostratigraphic interpretations, is not characterized by marked changes in microfaunal and microfloral composition or in abyssal sedimentation, except for some sudden marked quantitative variations in clay-mineral composition, also known to occur in many other localities at the same period.

From a paleobiogeographic perspective, there is a remarkable evolution from markedly endemic Albian to Coniacian foraminiferal and radiolarian associations, still with a significant proportion of Tethyan forms, to much more cosmopolitan associations from the early Coniacian onward. The data from Leg 159 demonstrate that, although an oceanic opening between the North and South Atlantic is probable from the Albian (mid-late Albian precisely), circulation must have remained relatively restricted in the region of the CIGMR until the Coniacian.

The multiple biostratigraphic studies conducted on the material from Leg 159 improve the age assignments of the lithological units shown on seismic profiles and provide more precise age constraints for dating the paleoceanographic and geodynamic events registered in this area. However, the absence of magnetostratigraphic data and the relatively poor calibration of some zonal schemes in equatorial latitudes (in particular, the ones based on palynomorphs), imposes restriction on the interpretation of these initial results and care has to be taken not to overinterpret the data.

\section{ACKNOWLEDGMENTS}

We thank William V. Sliter and Jürgen Thurow for their constructive reviews of the manuscript. This is contribution $n^{\circ} 156$ of the UMR-CNRS “Géosciences Azur”, Nice.

\section{REFERENCES}

Allix, P., Grosdidier, E., Jardiné, S., Legoux, O., and Popoff, M., 1981. Découverte d'Aptien supérieur à Albien inférieur daté par microfossiles dans la série détritique crétacée du fossé de la Bénoué (Nigéria). C. $R$. Acad. Sci., Ser. D, 292:1291-1294.

Bonatti, E., Ligi, M., Borsetti, A.M., Gasperini, L., Negri, A., and Sartori, R., 1996. Lower Cretaceous deposits trapped near the equatorial MidAtlantic Ridge. Nature, 380:518-520.

Brinkhuis, H., and Zachariasse, W.J., 1988. Dinoflagellate cysts, sea level changes and planktonic foraminifers across the Cretaceous-Tertiary boundary at El Haria, northwest Tunisia. Mar. Micropaleontol., 13:153191.

Chamley, H., Debrabant, P., and Flicoteaux, R., 1988. Comparative sedimentology of the Senegal and eastern central Atlantic Basins, from mineralogical and geochemical investigations. Sedimentology, 35:85-103.

Deconinck, J.F., 1992. Sédimentologie des argiles dans le Jurassique-Crétacé d'Europe occidentale et du Maroc [Habilit. thesis]. Lille Univ.

Firth, J.V., 1993. Dinoflagellate assemblages and sea-level fluctuations in the Maastrichtian of southwest Georgia. Rev. Palaeobot. Palynol., 79:179204.

Förster, R., 1978. Evidence for an open seaway between northern and southern proto-Atlantic in Albian times. Nature, 272:158-159.

Geroch, S., and Nowak, W., 1984. Proposal of zonation for the late Tithonian-Eocene, based upon the arenaceous foraminifera from the outer Carpathians, Poland. In Oertli, H.J. (Ed.), BENTHOS '83: 2nd Int. Symp. 
Benthic Foraminifera. Bull. Cent. Rech. Explor.-Prod. Elf-Aquitaine, 6:225-239.

Habib, D., Moshkovitz, S., and Kramer, C., 1992. Dinoflagellate and calcareous nannofossil response to sea level changes in Cretaceous-Tertiary boundary sections. Geology, 20:165-168.

Hansen, J.M., 1977. Dinoflagellate stratigraphy and echinoid distribution in Upper Maastrichtian and Danian deposits from Denmark. Bull. Geol. Soc. Den., 26:1-26.

, 1979a. A new dinoflagellate zone at the Maastrichtian/Danian boundary in Denmark. Dan. Geol. Unders. Arbog, 1978:131-140.

1979b. Dinoflagellate zonation around the boundary. In Birke-

lund, T., and Bromley, R.G. (Eds.), Cretaceous-Tertiary Boundary Events, Symp. I: The Maastrichtian and Danian of Denmark: Univ. Copenhagen, 136-143.

Haq, B.U., Hardenbol, J., and Vail, P.R., 1987. Chronology of fluctuating sea levels since the Triassic. Science, 235:1156-1167.

Kirsch, K.H., 1991. Dinoflagellaten-Zysten aus der Oberkreide des Helvetikums und Nordultrahelvetikums von Oberbayern. Münchner Geowiss. Abh., Reihe A, Geol. Palaeontol., 22:1-306.

Kuhnt, W., 1992. An early Campanian paleoceanographic event in the North Atlantic and Western Tethys? Fourth Int. Conf. Paleoceanogr., ICP IV. Geomar Rep. 15/Rep., Geol. Palaeontol. Inst. Univ. Kiel, 57:171.

Mascle, J., Blarez, E., and Marinho, M., 1988. The shallow structures of the Guinea and Ivory Coast-Ghana transform margins: their bearing on the Equatorial Atlantic Mesozoic evolution. Tectonophysics, 188:193-209.

Mascle, J., Lohmann, G.P., Clift, P.D., et al., 1996. Proc. ODP, Init. Repts., 159: College Station, TX (Ocean Drilling Program).

Moullade, M., and Guérin, S., 1982. Le problème des relations de l'Atlantique Sud et de l'Atlantique Central au Crétacé moyen: nouvelles données microfauniques d'après les forages D.S.D.P. Bull. Soc. Geol. Fr., 24:511-517.

Moullade, M., Kuhnt, W., and Thurow, J., 1988. Agglutinated benthic foraminifers from Upper Cretaceous variegated clays of the North Atlantic
Ocean (DSDP Leg 93 and ODP Leg 103). In Boillot, G., Winterer, E.L., et al., Proc. ODP, Sci. Results, 103: College Station, TX (Ocean Drilling Program), 349-377.

Moullade, M., Mascle, J., Benkhelil, J., Cousin, M., and Tricart, P., 1993. Occurrence of marine mid-Cretaceous sediments along the Guinean slope (Equamarge II cruise): their significance for the evolution of the central Atlantic African margin. Mar. Geol., 110:63-72.

Ortega-Huertas, M., Martinez-Ruiz, F., Palomo, I., and Chamley, H., 1995. Comparative mineralogical and geochemical clay sedimentation in the Betic Cordilleras and Basque-Cantabrian Basin areas at the CretaceousTertiary boundary. Sediment. Geol., 94:209-227.

Pletsch, T., Erbacher, J., Holbourn, A., Kaminski, M.A., de Klasz, S., Kuhnt, W., and Moullade, M., 1996. The Cretaceous of the Gulf of Guinea (Leg 159) and adjacent coastal basins: implications for the opening of the Equatorial Atlantic Gateway. Ber-Rep., Geol.-Palaeontol. Inst. Univ. Kiel, 76:201-205.

Pollastro, R.M., and Pillmore, C.L., 1987. Mineralogy and petrology of the Cretaceous-Tertiary boundary clay bed and adjacent clay-rich rocks, Raton Basin, New Mexico and Colorado. J. Sediment. Petrol., 57:456466.

Wiedmann, J., and Neugebauer, J., 1978. Lower Cretaceous ammonites from the South Atlantic Leg 40 (DSDP), their stratigraphic value and sedimentologic properties. In Bolli, H.M., Ryan, W.B.F., et al., Init. Repts. DSDP, 40: Washington (U.S. Govt. Printing Office), 709-734.

Date of initial receipt: 20 May 1997

Date of acceptance: 7 August 1997 Ms 159SR-049 